\title{
Abū ‘Abd al-Raḥmān al-Sulami, Elena Biagi. A Collection of Sufi Rules of Conduct. Traduit par Elena Biagi
}

Ève Feuillebois-Piérunek

\section{(2) OpenEdition \\ 12 Journals \\ Édition électronique \\ URL : http://journals.openedition.org/abstractairanica/40329 \\ DOI : 10.4000/abstractairanica.40329 \\ ISSN : 1961-960X \\ Éditeur : \\ CNRS (UMR 7528 Mondes iraniens et indiens), Éditions de l'IFRI}

\section{Édition imprimée}

Date de publication : 1 décembre 2013

ISSN : 0240-8910

Référence électronique

Ėve Feuillebois-Piérunek, « Abū 'Abd al-Rahmān al-Sulami, Elena Biagi. A Collection of Sufi Rules of Conduct. Traduit par Elena Biagi », Abstracta Iranica [En ligne], Volume 32-33 | 2013, document 381, mis en ligne le 01 juillet 2016, consulté le 02 octobre 2020. URL : http://journals.openedition.org/ abstractairanica/40329; DOI : https://doi.org/10.4000/abstractairanica.40329

Ce document a été généré automatiquement le 2 octobre 2020.

Tous droits réservés 


\section{Abū 'Abd al-Raḥmān al-Sulami, Elena Biagi. A Collection of Sufi Rules of Conduct. Traduit par Elena Biagi}

Ève Feuillebois-Piérunek

\section{RÉFÉRENCE}

Abū 'Abd al-Rahmmān al-Sulami, Elena Biagi. A Collection of Sufi Rules of Conduct. Traduit par Elena Biagi. Cambridge, Islamic Texts Society, 2010, XLIX + 165 p.

1 Il s'agit de la première traduction anglaise du Jawāmi Ẩāb al-Ṣufiyya, un traité de dimension modeste mais de grande importance, qui tient à la fois du manuel de soufisme et de la littérature éthique. Elle est précédée d'une introduction replaçant l'auteur dans son contexte historique, littéraire et religieux et resituant le texte dans la littérature arabe et la tradition soufie. Après des éléments biographiques et la description des principales œuvres de Sulamī, E. Biagi présente la tradition littéraire arabe de l'adab, les prolongements soufis de l'adab comme étiquette et viatique sur la voie spirituelle, avant de décrire brièvement le contenu de ces Règles de conduite soufie. La traduction est richement annotée et suivie d'un précieux glossaire des termes techniques et de notes biographiques concernant les personnages importants mentionnés dans ce traité. Une biographie et un index complètent le livre qui constitue une avancée dans le domaine de la connaissance des débuts du « savoir-vivre » soufi. 


\section{AUTEURS}

\section{ÈVE FEUILLEBOIS-PIÉRUNEK}

Université Sorbonne Nouvelle-Paris 3, Mondes iranien et indien, Paris 